\title{
MEDIATION IN THE EU: COMMON CHARACTERISTICS AND ADVANTAGES OVER LITIGATION
}

\author{
Anna Shtefan* \\ Yurii Prytyka**
}

\begin{abstract}
Mediation is an alternative extrajudicial procedure intended to resolve a dispute quickly and efficiently. One of the tasks of mediation is also to relieve the judicial system because disputes whose parties can find a compromise in their legal conflict can be successfully resolved without court involvement. Although the many EU Member States have adopted specific legislation on mediation and the courts fully encourage the parties to resolve their disputes through extrajudicial procedures, mediation is still not widespread in the EU. This is largely due to the lack of structured information about mediation and its advantages over litigation. The purpose of this article is to present the main features of mediation in the EU and to highlight why mediation is more convenient, faster, more efficient, and more cost-effective. The advantages over litigation and the possibility of application in many disputes should contribute to the development of mediation which the European community strives to achieve.
\end{abstract}

KEYWORDS: Mediation; EU Directive on mediation; Advantages of mediation

\section{INTRODUCTION}

The judicial form of dispute resolution takes precedence over alternative dispute resolution. First, there are spheres of relations in which a dispute can be resolved only by a court because the law does not provide for another procedure for resolving such a dispute. This often applies to cases where a party is

\footnotetext{
* Anna Shtefan, Scientific Research Institute of the National Academy of Legal Sciences of Ukraine, Kyiv, Ukraine; anna_shtefan@ukr.net.

** Yurii Prytyka, Taras Shevchenko National University of Kyiv, Kyiv, Ukraine; law@cyrkon. kiev.ua.
} 
a subject of government authority and the dispute is related to the activities of this subject, in particular in the area of taxation, customs clearance of goods, issuing licenses for certain types of activities. Second, even when the law permits and encourages out-of-court settlements of legal conflicts, the parties to such conflicts may not be interested in doing so. If they have mutually exclusive interests when each party is demanding recognition of its right and neither of them is willing to make concessions, such a dispute requires the court to qualify the legal relationship of the parties and determine which of them has a right to a claim and who must comply with this requirement.

However, many disputes can be effectively resolved without the involvement of a court using alternative dispute resolution methods. Such procedures include, in particular, negotiation, arbitration, and mediation, which are used to resolve family, labor, and other civil and commercial disputes without going to court. In the EU, access to out-of-court dispute settlement procedures is seen as providing better access to justice, as highlighted in the Directive 2008/52/EC on certain aspects of mediation in civil and commercial matters (the Mediation Directive). Mediation, as one of these methods, is carried out with the assistance of mediators who help the parties to find a compromise and a solution that satisfies them both. In this case, the dispute settlement process is not adversarial which is typical of litigation but is collaborative in nature. This process is aimed not at establishing the guilt of one party for causing negative consequences to the other party, but at finding a way out of the legal conflict on mutually beneficial terms. Moreover, in the light of the large workload of the judicial system, the time for out-of-court settlement of a dispute is usually much shorter, that is, stakeholders can resolve the legal conflict and also do so more quickly.

Many Member States have adopted separate laws on mediation, in particular, Austria, ${ }^{2}$ Croatia, ${ }^{3}$ Germany, ${ }^{4}$ Ireland, ${ }^{5}$ Italy, ${ }^{6}$ Spain. ${ }^{7}$ There are many medi-

1 Directive 2008/52/EC of the European Parliament and of the Council of 21 May 2008 on certain aspects of mediation in civil and commercial matters (OJ L 136, 24.5.2008, p. 3-8), Para. 5 of the preamble.

2 Bundesgesetz über Mediation in Zivilrechtssachen (StF: BGBl. I Nr. 29/2003).

3 Zakon o mirenju (NN 18/11, 2011) [https://www.zakon.hr/z/169/Zakon-o-mirenju], accessed on 23/09/2021.

4 Mediationsgesetz vom 21. Juli 2012 (BGBl. I S. 1577, 2012).

5 The Mediation Act 2017 [http://www.irishstatutebook.ie/eli/2017/act/27/enacted/en/html], accessed on 23/09/2021.

6 Decreto Legislativo 4 marzo 2010, n. 28 Attuazione dell'articolo 60 della legge 18 giugno 2009 , n. 69, in materia di mediazione finalizzata alla conciliazione delle controversie civili e commerciali. (10G0050) (GU Serie Generale n.53 del 05-03-2010).

7 Ley 5/2012, de 6 de julio, de mediación en asuntos civiles y mercantiles (BOLETÍN OFICIAL DEL ESTADO 162, 2012, Sec. I). 
ation organizations that disseminate information about out-of-court dispute resolution. However, mediation is not yet as widely used as it could be.

In 2012, Dr. Stephan Prayer who for several years has served as president of the Austrian Society for Mediation in the Notariat noted that it is a fact that mediation has become better known in recent years and is seen and recognized as an enrichment to existing dispute resolution models. In the assessment of the European institutions, this is not happening to the anticipated and desired extent. ${ }^{8}$ In 2014, Roman Rewald called mediation "the most misunderstood method of alternative dispute resolution" and explained that in Poland alone, statistics on mediation use are dramatically low. The total number of commercial mediations initiated by Polish courts during the period of 2006-2011 was only 3,541, whereas Polish courts register approximately 1.25 million commercial cases annually'. ${ }^{9}$ In 2018, Giuseppe De Palo illustrated the paradox of mediation as 'universally praised and promoted but still used in less than 1 percent of the cases in civil and commercial litigation in the EU'. ${ }^{10}$

The situation should have improved somewhat over the years but today there are no European statistics on the number of proceedings and the percentage of disputes resolved without going to court compared with the number of disputes resolved by the courts that could have been resolved through mediation. Therefore, it is impossible to trace the dynamics of mediation and illustrate it with precise indicators.

However, there is doubt that the demand for these services has suddenly increased and now accounts for a significant percentage of all civil and commercial disputes that can be resolved by alternative means. In our opinion, one of the main reasons for this problem is a lack of awareness of mediation and the opportunities it provides. Although there is a lot of information about mediation, it is sometimes insufficiently structured and the advantages of mediation over litigation are not fully understood. Therefore, the purpose of this article is to form a comprehensive view of mediation in the EU, which will explain

8 Prayer, S.: Why is mediation not used more often as a means of alternative dispute resolution? European Parliament's Committee on Legal Affairs, Brussels, 2012, p. 7 [https:// www.europarl.europa.eu/document/activities/cont/201212/20121219ATT58302/20121219ATT58302EN.pdf], accessed on 23/09/2021.

9 Rewald, R.: Mediation in Europe: The Most Misunderstood Method of Alternative Dispute Resolution, The Wail World Arbitration Report, 2014, p. 14 [https://www.weil.com/ /media/ files/pdfs/WWAR_Newsletter_Spring2014.pdf], accessed on 23/09/2021.

10 Palo, G.: A Ten-Year-Long "EU Mediation Paradox". When an EU Directive Needs To Be More ...Directive, 2018, p. 1 [https://op.europa.eu/en/publication-detail/-/publication/315d 31c7-f132-11e8-9982-01aa75ed71a1/language-en/format-PDF/source-166607091] accessed on $10 / 12 / 2021$. 
the appropriateness of its application. In Part 2 of this article, we analyze the main features of mediation in the EU and reveal its key characteristics, thus providing an understanding of the fundamentals on which mediation is based. In Part 3, we explain why mediation can be more effective than litigation and what the advantages of mediation are.

\section{MAIN PROVISIONS ON THE MEDIATION IN THE EU}

Mediation is an alternative extrajudicial dispute resolution procedure, the key concepts of which are defined in the Mediation Directive and the European Code of Conduct for Mediators (European Mediators Code). ${ }^{11}$

Mediation is a structured process, however, named or referred to, whereby two or more parties to a dispute attempt by themselves, on a voluntary basis, to reach an agreement on the settlement of their dispute. ${ }^{12}$ An important characteristic of mediation emerges from this provision, such as the voluntary action of the parties when each of them seeks to overcome the legal conflict between them. Mediation is based on the "principle of self-determination"13 which allows the parties to decide whether or not to participate in the dispute resolution process. Voluntary participation in extrajudicial dispute resolution is also explained by the provision according to which the parties may withdraw from the mediation at any time without giving any justification. ${ }^{14}$ No one has the right to compel a party to participate in mediation if it decides that its continued participation is inappropriate for any reason or ground. It is worth supporting the idea that 'the parties make their own decisions in the mediation process completely free in resorting to this process, in maintaining the process, and in positively or negatively finalizing the process. ${ }^{15}$ Therefore, the parties are free to initiate mediation, make any decision in the course of this procedure and refuse mediation at any stage.

It should be noted that the mediation procedure can be initiated not only by the parties but also by the court. It may invite the parties to use mediation when

\footnotetext{
11 European Code of Conduct for Mediators of the European Commission. 2004 [https:// www.euromed-justice.eu/en/document/eu-european-code-conduct-mediators], accessed on 23/09/2021.

12 Mediation Directive, Art. 3(a).

13 Rubinson, R.: Client Counseling, Mediation, and Alternative Narratives of Dispute Resolution, Clinical Law Review 10(Spring) 2004, p. 850.

14 European Mediators Code, Art. 3.3.

15 Dursun, A.: The Principle of Confidentiality In Mediation and the Role of Confidentiality In Commercial Mediation, Afro Eurasian Studies Journal 6(1\&2) 2017, p. 19.
} 
it is appropriate and having regard to all the circumstances of the case.$^{16}$ The court exercises this power when mediation is justified and reasonable when the resolution of the dispute does not require control by the court. At the same time, the parties should not be obliged to agree to mediation. They should have discretion in this matter, and if at least one-party objects to the use of mediation, the court should not refuse to continue the hearing proceedings. The Mediation Directive does not contain any rules in this regard; such provisions may be laid down in the domestic law of the Member States. In this case, it is important that if the parties to the dispute do not see the possibility of reconciliation and require that their rights and obligations be determined by a court, the non-judicial dispute resolution system should not replace the judicial system or limit the exercise of the right to judicial protection.

Also, a mandatory mediation may be prescribed by the law of a Member State. ${ }^{17}$ The Mediation Directive delegates to each state the authority to determine when mediation is mandatory with one condition that such legislation does not prevent the parties from exercising their right of access to the judicial system..$^{18}$ In such cases, participation in out-of-court dispute resolution is not entirely voluntary. Such participation is not due to the will of the parties but to a legal provision mandating the mediation procedure. Although the parties may terminate their participation in the mediation procedure at any stage, there is no possibility for their initiative to launch this procedure. This allows us to clarify that in today's environment mediation is voluntary only to a certain extent.

Mediation is not conducted directly between the parties to a dispute but with the participation of a mediator. The mediator is not a kind of judge, his or her task is to facilitate the process of dispute resolution, 'to provide enough structure so opportunities for resolution can be developed and explored', 19 'to help parties to understand the nature of the problem, the underlying interests of all parties, and the various options that may exist to help resolve all, or part, of the problem', ${ }^{20}$ 'to assist parties in shaping solutions to meet their interests and objectives'. ${ }^{21}$ The Mediation Directive states that the mediator is any third per-

\footnotetext{
16 Mediation Directive, Art. 5(1).

17 Ibid.

18 Ibid, Art. 5(2).

19 Bennett, M.; Hughes, S.: The Art of Mediation, Notre Dame, 2005, p. 18.

20 Doneff A.; Ordover A.: Alternatives to Litigation: Mediation, Arbitration, and the Art of Dispute Resolution, 3rd edition, Boulder, 2014, p. 13.

21 Menkel-Meadow, C. at al:: Dispute Resolution: Beyond the Adversarial Mode, 3rd edition, New York, 2019, p. 29.
} 
son who is asked to conduct the mediation in an effective, impartial, and competent way, regardless of the denomination or profession of that third person in the Member State concerned and of the way in which the third person has been appointed or requested to conduct the mediation. ${ }^{22}$ This provision covers an unlimited number of persons who are potentially able to assist the parties in resolving the dispute. Such persons should satisfy three main requirements: efficiency, impartiality, and competence.

The competence of the mediator is disclosed in the European Mediators Code in the form of the rule under which the mediator shall be knowledgeable in the process of mediation. ${ }^{23}$ This provision is rather abstract; it does not contain specific criteria or requirements. Such criteria or requirements can be established by the legislation of the Member States, for example, in Hungary the mediator should have a degree in higher education and practical experience in the respective field should contain at least five years, ${ }^{24}$ in Belgium theoretical background of the mediator should include issues related to jurisprudence. ${ }^{25}$ There are also requirements for a mediator in the rules of the mediation organizations. In particular, the International Mediation Institute has developed a fairly large list of minimum standards for Certified Mediation Advocates which include the experience of the mediation process knowledge of mediation advocacy, and practical mediation advocacy skills. ${ }^{26}$ Similarly, European organizations responsible for licensing or certifying mediators determine the conditions that must be met for a person to be entered in the register of mediators and authorized to provide dispute settlement services. A mediator's competence is achieved through initial and subsequent training during which the mediator acquires the theoretical and practical skills necessary to effectively conduct the dispute resolution process.

However, the training of mediators in the Member States is different, with 'accreditation or certification programs varying from thirty to three-hundred hours'. ${ }^{27}$ Too short training is unlikely to provide the necessary level of professionalism for a mediator while too extensive a training program may not

\footnotetext{
22 Mediation Directive, Art. 3(b).

23 European Mediators Code, Art. 1.1.

24 Act on Mediation No. 55 of 2002, Art. 5(1)(a) (HUN-2002-L-71703).

25 Le Code judiciaire, 10 Octobre 1967,Art. 1726 (1) [http://www.ejustice.just.fgov.be/cgi_loi/ change_lg.pl?language $=$ fr\&la $=F \& c n=1967101004 \&$ table_name $=l o i]$ accessed on 10/12/2021.

26 International Mediation Institute: Competency Criteria [https://imimediation.org/practitioners/competency-criteria], accessed on 10/12/2021.

27 Cominelli, L.: Training Young Lawyers in the European Mediation Framework: It's Time to Devise a New Pedagogy for Conflict Management and Dispute Resolution, The Italian Law Journal 2(1) 2016, p. 166.
} 
be sufficiently effective either. To ensure the effectiveness of mediation, the European Mediators Code provides that the mediator shall satisfy him/herself as to his/her background and competence to conduct the mediation before accepting the appointment. ${ }^{28}$ That is, the mediator must make sure that he/she has sufficient knowledge and experience to conduct the mediation, that he/she is able to provide the parties with all the conditions for resolving the dispute. The effectiveness of mediation is also ensured by the fact that the mediator has the right to terminate the dispute resolution procedure if, based on the circumstances of the case and his/her competence, he/she believes that a settlement is being reached that for the mediator appears unenforceable or illegal or continuing the mediation is unlikely to result in a settlement. ${ }^{29} \mathrm{In}$ such cases, mediation will not lead to a real resolution of the dispute, and therefore it will not be effective.

As for impartiality, the mediator's neutral position is recognized as one of the most important conditions of mediation. ${ }^{30}$ The mediator must not have any connection with the dispute that could interfere with the proper conduct of the procedure. The European Mediators Code indicates three cases when a mediator may refuse to conduct mediation: any personal or business relationship with one of the parties; any financial or other interest, direct or indirect, in the outcome of the mediation; the mediator, or a member of his or her firm, having acted in any capacity other than mediator for one of the parties. ${ }^{31}$ The occurrence of any of these cases restricts the mediator's ability to conduct the mediation because there are no exceptions to the rule that the mediator should be 'strictly neutral and scrupulously fair to all parties'..$^{32}$ In the event of a conflict of interest, the mediator must inform the parties to the dispute and may only provide his/her services if he/she is confident that he/she can act impartially and if the parties to the dispute, having been informed of the conflict of interest, have expressed their explicit consent to the mediator to conduct the dispute resolution procedure. ${ }^{33}$

A judge may also act as a mediator if this judge is not responsible for any judicial proceedings concerning the dispute in question. ${ }^{34}$ The Mediation Directive

\footnotetext{
28 European Mediators Code, Art. 1.2.

29 Ibid, Art. 3.2.

30 Keltner, J.: Toward a Civilized System of Dispute Resolution, Illinois, 1987, p. 9.

31 European Mediators Code, Art. 2.1.

32 Feinberg, K.: Mediation - a Preferred Method of Dispute Resolution, Pepperdine Law Review 16(5) 1989, p. 13-14.

33 European Mediators Code, Art. 2.1.

34 Mediation Directive, Art. 3(a).
} 
specifies that the concept of mediation excludes attempts made by the court or the judge seised to settle a dispute in the course of judicial proceedings concerning the dispute in question. ${ }^{35}$ Thus, a mediator can be a judge who is not connected in any way with a case that was considered in the court before the mediation procedure. That is, it is a person who holds the position of a judge but is not a judge in that particular case, a person who did not participate in the consideration of the case and did not perform any procedural actions in the case.

The mediation procedure is confidential. The Mediation Directive and the European Mediators Code disclose this provision in different ways.

In terms of the Mediation Directive, confidentiality means that, except as specifically provided for, neither mediators nor those involved in the administration of the mediation process shall be compelled to give evidence in civil and commercial judicial proceedings or arbitration regarding information arising out of or in connection with a mediation process. ${ }^{36}$ This rule establishes the immunity of the mediator and persons involved in the administration of the mediation process who may not be questioned as witnesses in civil and commercial cases or in arbitration concerning any information that became known to them in connection with mediation.

Instead, the European Mediators Code defines confidentiality as a mediator's duty to keep confidential all information, arising out of or in connection with the mediation, including the fact that the mediation is to take place or has taken place unless compelled by law or public policy grounds, as well as to don't disclose information received from one party to the other party without that party's permission unless otherwise provided by law. ${ }^{37}$ In this case, confidentiality is internal and limits the dissemination of information from the mediator to the mediating party.

In out-of-court dispute resolution procedures, confidentiality is necessary to prevent the dissemination of information that is not publicly available and becomes known during mediation. Such information includes, in particular, personal data, details of the personal life of individuals, trade secrets of legal entities. Therefore, there is no doubt that 'all offers, promises, conduct and statements, whether oral or written, made in the course of the mediation process by any of the parties or their representatives, are confidential'. ${ }^{38}$ Confidentiality is also given to any other information that a party provides to the

\footnotetext{
35 Ibid.

36 Ibid, Art. 7(1).

37 European Mediators Code, Art. 4.

38 Feinberg, K.: Mediation - a Preferred Method of Dispute Resolution, Pepperdine Law Review 16(5) 1989, p. 14.
} 
mediator, due to the need to protect the interests of the party in the dispute resolution procedure. Therefore, the confidentiality of mediation should extend to keeping such information secret both within and outside the procedure.

However, the confidentiality regime should be established in such a way that mediation statistics can be compiled. This problem was mentioned in the Main conclusions of the Mediation Directive Report where the attention is paid to the difficulty of obtaining comprehensive statistical data on mediation, including the number of mediated cases, the average length and success rates of mediation processes and also noted that "without a reliable database it is very difficult to further promote mediation and increase public trust in its effectiveness' ${ }^{39}$ Indeed, the development of alternative methods of dispute resolution will proceed faster if there is access to information about the procedures conducted, their duration, cost, and the results achieved. Such information will be very useful for future mediators; it will help the parties to a dispute to determine the advantages of mediation over litigation. Such information is also necessary for analytical research so the confidentiality regime should leave some space for mediation awareness.

Mediation is intended for voluntary participation in the procedure but also for the voluntary execution of the settlement concluded as a result of mediation. However, if one party evades the settlement, the other party needs assurances that the settlement will nevertheless be implemented. These guarantees are expressed in the fact that the court or other authorized body may enforce the agreement at the request of a party. The Mediation Directive clarifies that the content of such an agreement shall be made enforceable unless, in the case in question, either the content of that agreement is contrary to the law of the Member State where the request is made or the law of that Member State does not provide for its enforceability. ${ }^{40}$ If this possibility is not established by law, it carries the potential risk that out-of-court dispute resolution will be futile and will not lead to the real consequences agreed in mediation. It should be noted that no provision of the Mediation Directive prevents a party to the mediation from applying to a court to resolve the same dispute. ${ }^{41}$ At the same time, the lack of guarantees of execution of the mediation settlement in some cases can

\footnotetext{
39 Report on the implementation of Directive 2008/52/EC of the European Parliament and of the Council of 21 May 2008 on certain aspects of mediation in civil and commercial matters (the 'Mediation Directive') (2016/2066(INI)) [https://www.europarl.europa.eu/doceo/document/A-8-2017-0238_EN.html], accessed on 12/10/2021.

40 Mediation Directive, Art. 6(1).

41 Moreover, the Mediation Directive specifies in Art. 8(1) that parties who choose mediation in an attempt to settle a dispute are not subsequently prevented from initiating judicial proceedings or arbitration in relation to that dispute by the expiry of limitation or prescription
} 
only lead to the loss of time and money to pay for mediation if the party will still have to apply to the court to resolve the same dispute. It will also not help to unload the judicial system which is one of the goals of extrajudicial dispute resolution. Therefore, the guarantee of execution of the settlement the content of which is not contrary to the law is one of the basic principles of mediation. This principle ensures the appropriateness and effectiveness of mediation.

Thus, mediation in the EU is characterized by a combination of several features. Participation in extrajudicial dispute resolution is voluntary but the law may establish cases of mandatory mediation. Extrajudicial dispute resolution is conducted by a mediator who can be any person, including a judge who has no relation to the case that was considered by the court before the mediation procedure began. The mediator must conduct the procedure efficiently, impartially, competently, and fairly. Mediation is confidential, which includes keeping information secret both within the procedure and outside it. A settlement as a result of the resolution of the dispute is ensured by the possibility of its implementation. Taken together, these features make mediation transparent, understandable, and safe in terms of non-disclosure, which should make mediation attractive to the parties to a dispute. In addition, mediation has other features which suggest that extrajudicial dispute resolution is often the better alternative to litigation. These features will be discussed in detail below.

\section{ADVANTAGES OF MEDIATION COMPARED TO THE JUDICIAL FORM OF DISPUTE RESOLUTION}

Mediation differs from litigation in several important criteria. These differences show that dispute resolution through mediation can be not only effective but also more convenient and comfortable for the parties.

First, mediation is informal as the parties themselves determine how the procedure will be conducted and what stages or elements it will consist of. The mediation process has no "fixed set of rules', ${ }^{42}$ moreover, it can always be adapted to the needs of the parties who can hold individual meetings with the mediator and joint meetings as needed. The parties are directly involved in the management of mediation and do so at their discretion. Judicial proceedings are not individualized as the law establishes mandatory procedures and stages of proceedings. The trial is burdened with many rules that cannot be influ-

periods during the mediation process, i.e. the mediation period is not included in the limitation or prescription periods.

42 Shamir, Y.: Alternative Dispute Resolution Approaches and Their Application, 2016, p. 24 [https://biblioteca.cejamericas.org/bitstream/handle/2015/721/Alternative-Dispute-Resolution-Approaches.pdf?sequence=1\&isAllowed=y], accessed on 10/12/2021. 
enced by the parties to the dispute. It is not flexible, and it is not adapted to the wishes or needs of the parties. The parties to litigation are obliged to comply with numerous requirements related to the execution of procedural documents, compliance with the procedure for their filing, and so on, and failure to comply with these requirements leads to negative consequences. The mediation procedure has no such requirements. A mandatory step is the conclusion of an agreement with a mediator under which extrajudicial resolution services will be provided but all other terms and procedures are established by the parties.

Second, the parties themselves determine how to resolve their legal conflict. In mediation, there is no dispute resolution but a joint agreement between the parties on how to deal with the situation between them. There is no such notion as 'fault' or 'responsibility' in mediation; ${ }^{43}$ the settlement of the dispute does not require recognition that 'one or the other party be found in the wrong'. ${ }^{44}$ Mediation in this sense is the search for a compromise and the development of a mutually beneficial solution that takes into account the interests of both parties. The mediator helps the parties to establish constructive communication but in no way affects the content of the settlement between the parties: 'power is vested in the parties, who have control over the outcome: they are the architects of the solution'. ${ }^{45}$ In contrast, litigation focuses on resolving a dispute on the merits, that is, establishing what actions have been taken by the parties, giving them legal qualifications, and determining which party is liable to the other party and to what extent. The dispute is decided by the judge (or a jury, if provided by the law of the state) at their discretion, and only one party's interests may be considered in deciding each separate point in the claim, namely, whether to dismiss the request or grant it. Plaintiff and defendant are procedural rivals who have opposing positions and mutually exclusive interests, so finding a compromise can never be the goal of litigation. Thus, in mediation, the settlement of a dispute depends solely on the parties who independently make a joint decision in their dispute and are free to create any solution, 'in any form, sort, and depth that is agreeable'. ${ }^{46}$ The mediator is only facilitating that the decision 'accounts for the needs and interests of all concerned' ${ }^{47}$ In

43 Rubinson, R.: Client Counseling, Mediation, and Alternative Narratives of Dispute Resolution, Clinical Law Review 10(Spring) 2004, p. 852.

44 Feinberg, K.: Mediation - a Preferred Method of Dispute Resolution, Pepperdine Law Review 16(5) 1989, p. 6.

45 Shamir, Y.: Alternative Dispute Resolution Approaches and Their Application, 2016, p. 23 [https://biblioteca.cejamericas.org/bitstream/handle/2015/721/Alternative-Dispute-Resolution-Approaches.pdf?sequence=1\&isAllowed=y], accessed on 10/12/2021.

46 Bennett, M.; Hughes, S.: The Art of Mediation, Notre Dame, 2005, p. 17.

47 Bush, R.; Folger, J.: Mediation and Social Justice: Risks and Opportunities, Ohio State Journal on Dispute Resolution 27(1) 2012, p. 13. 
court proceedings, the function of resolving the dispute is vested in the court and this does not imply a mutually beneficial nature of the court decision. Even more, a court decision may not satisfy either party while the mediation settlement reflects the interests of both parties.

Third, mediation focuses on what will happen in the future. 'Mediation rejects the idea that 'what happened' is a unitary or stable 'truth' to be found 'out there'. ${ }^{48}$ In this procedure, the retrospective establishment of all the circumstances of the conflict is irrelevant. There are no rules of evidence and no need for it; it is enough that the parties are aware of the situation between them. Although the parties may exchange some documents to provide them with more information on certain aspects of the legal conflict, there are no requirements for the execution and submission of these documents. The key to mediation is deciding how to proceed in the future. On the contrary, litigation is inconceivable without evidence through which each party must prove its claims and defenses. To decide what action should be taken by a party in the future, the court needs to establish the circumstances of the case; that is, the trial is essentially concerned with establishing past events. In addition, the law establishes several requirements for the execution and submission of evidence that must be met. The court may reject some evidence as irrelevant or inadmissible; thus, proving in a trial requires considerable effort and deep knowledge of all the rules and procedures. In mediation there are no such difficulties, the parties are free to exchange any documents they consider necessary. This is not done to establish the facts of the case but to better understand the essence of the dispute which will contribute to its resolution.

Fourth, mediation does not require a professional representative who is familiar with the law and protects the interests of the party being represented. Mediation does not belong to the practice of law; as correctly noted, 'the mediator does not give legal advice, advice or represent clients, prescribe courses of action, or champion the cause of one side at the expense of the other' ${ }^{49}$ The parties do not seek to acknowledge who is at fault for the legal conflict but rather seek a way out of it. While each party may request legal assistance, consult with a lawyer, and invite a lawyer to participate in mediation, this is not a prerequisite for an extrajudicial resolution of a dispute. If the parties intend to agree, with a high degree of probability, mediation will lead to positive results without the involvement of lawyers. The same cannot be said of a trial which is usually a kind of ring in where lawyers "box" with evidence and arguments and the judge is the "referee". Even if the law allows individuals and legal entities

48 Rubinson, R.: Client Counseling, Mediation, and Alternative Narratives of Dispute Resolution, Clinical Law Review 10(Spring) 2004, p. 851.

49 Keltner, J.: Toward a Civilized System of Dispute Resolution, Illinois, 1987, p. 8-9. 
to defend their own interests, litigation is often ineffective for a party who has not received qualified assistance especially if the other party uses the services of a lawyer. Litigation usually requires significant preparation which includes developing a strategy, gathering evidence, arguing, analyzing an opponent's legal position, preparing procedural documents, and many other aspects. It is quite difficult to provide all this without the participation of a lawyer. In mediation, the most important role is played by the readiness for dialogue and compromise and the desire to resolve the dispute, while the involvement of a lawyer is usually secondary, and the procedure can be successfully carried out without legal assistance.

Fifth, the parties incur significantly lower costs in the process of resolving their dispute through mediation. Litigation, in addition to lawyer's fees, involves payment of various fees for filing a lawsuit, performing procedural actions, the work of an expert. The exact amount of court costs often cannot be determined in advance as the case may have complications that will require additional proceedings involving payment of certain fees or reimbursement of costs. In contrast, the cost of mediation is set at a fixed amount that is made known to the parties before the dispute resolution procedure begins and is usually much lower than the anticipated cost of comparatively simple litigation.

Sixth, the timeframe for extrajudicial dispute resolution is much shorter than the length of court proceedings. The extremely high workload of courts does not allow them to quickly consider and resolve a significant number of cases and leads to the formation of queues. The break between court sessions can take weeks or even months because the judge already has a schedule of other cases and objectively there is no way to conduct a court session faster. In the mediation procedure, the schedule of meetings is set by the parties themselves and agreed with the mediator. If both parties are active and the dialogue between them is constructive, the dispute can be resolved within a few days. Thus, the undoubted advantage of mediation is its operational efficiency as compared to the judicial process.

Seventh, mediation is confidential, so all information regarding the dispute resolution procedure and its results are not disclosed unless expressly required by law. No third party may be admitted to the mediation unless the parties themselves agree to the participation of such a person. This could be, for example, an expert or witness providing additional information to the parties or an interpreter for a party who is not sufficiently proficient in the language of the proceeding. The confidentiality regime usually applies to such a third party. As for the trial, it is open except in cases specifically provided by law. The hearing may be attended by the public or mass media, law students, and law firm interns who are learning the hearing procedure. In other words, var- 
ious outsiders may be present at the hearing. However, court hearings are not confidential, and therefore the information obtained during the hearings may be disseminated from the persons who received it to any other persons. In addition, in many countries, the full texts of judgments are posted on the websites of individual courts or the general portal of the judicial system, and everyone can read these decisions. Therefore, confidentiality in court proceedings can be ensured only in certain cases when it is provided by law. Confidentiality may not be important in all cases but it also supports the choice of mediation procedure because it ensures that many details that the parties do not wish to disclose are kept secret.

Eighth, mediation helps to maintain trust between the parties, their friends or family, or partnership relations. This criterion is not universal because the conflict between the parties can be so acute that even settling the dispute will not help them to treat each other kindlier. However, in general, mediation takes place in a neutral atmosphere of cooperation, where each party can comment on everything that seems important to it. The parties in mediation are not competing with each other but working to find the best solution for everyone as the mediation 'seeks to encourage cooperation among the parties, not only concerning the immediate dispute, but also concerning structuring their relationship in the future'. ${ }^{50}$ In litigation, by virtue of the adversarial principle, each party acts in its own interests and at the same time against the other party. The desire to convince the court of the correctness of their position and to achieve the satisfaction of their claims forms a tense procedural competition and can completely destroy the relationship between the parties. Of course, this does not happen in every case but there is a risk of damaging the relationship as a result of a court decision while mediation does not carry such a risk.

All these aspects clearly illustrate that, compared to litigation, mediation is more convenient, efficient, cost-effective, and psychologically comfortable. This suggests that mediation has great potential to develop and become more widespread as it serves as an effective and user-friendly method of dispute resolution.

\section{CONCLUSION}

Mediation in the EU combines all the optimal characteristics and features that ensure its functionality, efficiency, and at the same time simplicity of use. However, the legislative consolidation of the possibility of extrajudicial dispute resolution is not enough to popularize and develop the mediation. The

50 Feinberg, K.: Mediation - a Preferred Method of Dispute Resolution, Pepperdine Law Review 16(5) 1989, p. 11. 
lack of official statistics makes it impossible to say for sure, but reports from individual researchers suggest that the percentage of disputes resolved through mediation is still low. Although alternative procedures can be used in many types of disputes, the parties often prefer to use the court system rather than the mediator's services.

In this regard, it seems very important to further disseminate information about mediation in the context of highlighting its convenience, efficiency, and advantages over litigation. It can also be very useful to compile and publish statistics on mediation that will provide information on the nature of the dispute, the duration and cost of mediation, and its results. This can serve as an additional factor that will help the parties to the dispute to analyze the situation and choose mediation as a faster, more convenient, and cost-effective method of resolving the dispute.

\section{LITERATURE}

1. Act on Mediation No. 55 of 2002 (HUN-2002-L-71703).

2. Bennett, M.; Hughes, S.: The Art of Mediation, Notre Dame, 2005.

3. Bundesgesetz über Mediation in Zivilrechtssachen (StF: BGBl. I Nr. 29/2003).

4. Bush, R.; Folger, J.: Mediation and Social Justice: Risks and Opportunities, Ohio State Journal on Dispute Resolution 27(1) 2012.

5. Cominelli, L.: Training Young Lawyers in the European Mediation Framework: It's Time to Devise a New Pedagogy for Conflict Management and Dispute Resolution, The Italian Law Journal 2(1) 2016.

- DOI: https://doi.org/10.2139/ssrn.2772084

6. Decreto Legislativo 4 marzo 2010, n. 28 Attuazione dell'articolo 60 della legge 18 giugno 2009, n. 69, in materia di mediazione finalizzata alla conciliazione delle controversie civili e commerciali. (10G0050) (GU Serie Generale n.53 del 05-032010).

7. Directive 2008/52/EC of the European Parliament and of the Council of 21 May 2008 on certain aspects of mediation in civil and commercial matters (OJ L 136, 24.5.2008, p. 3-8).

8. Doneff A.; Ordover A.: Alternatives to Litigation: Mediation, Arbitration, and the Art of Dispute Resolution, 3rd edition, Boulder, 2014.

9. Dursun, A.: The Principle of Confidentiality In Mediation and the Role of Confidentiality In Commercial Mediation, Afro Eurasian Studies Journal 6(1\&2) 2017.

10. European Code of Conduct for Mediators of the European Commission. 2004 [https://www.euromed-justice.eu/en/document/eu-european-code-conduct-mediators], accessed on 10/12/2021. 
11. Feinberg, K.: Mediation - a Preferred Method of Dispute Resolution, Pepperdine Law Review 16(5) 1989.

12. International Mediation Institute: Competency Criteria [https://imimediation.org/ practitioners/competency-criteria], accessed on 10/12/2021.

13. Keltner, J.: Toward a Civilized System of Dispute Resolution, Illinois, 1987.

14. Le Code judiciaire, 10 Octobre 1967, [http://www.ejustice.just.fgov.be/cgi_loi/ change_lg.pl?language $=$ fr\&la $=F \& c n=1967101004 \&$ table_name $=$ loi] accessed on $10 / 12 / 2021$.

15. Ley $5 / 2012$, de 6 de julio, de mediación en asuntos civiles y mercantiles (BOLETÍN OFICIAL DEL ESTADO 162, 2012, Sec. I).

16. Mediationsgesetz vom 21 Juli 2012 (BGBl. I S. 1577, 2012).

17. Menkel-Meadow, C. at al:: Dispute Resolution: Beyond the Adversarial Mode, 3rd edition, New York, 2019.

- DOI: https://doi.org/10.4324/9780367816681-28

18. Palo, G.: A Ten-Year-Long "EU Mediation Paradox". When an EU Directive Needs To Be More ...Directive, 2018 [https://op.europa.eu/en/publication-detail/-/ publication/315d31c7-f132-11e8-9982-01aa75ed71a1/language-en/format-PDF/ source-166607091] accessed on 10/12/2021.

19. Prayer, S.: Why is mediation not used more often as a means of alternative dispute resolution? European Parliament's Committee on Legal Affairs, Brussels, 2012 [https://www.europarl.europa.eu/document/activities/cont/201212/20121219ATT58302/20121219ATT58302EN.pdf], accessed on 10/12/2021.

20. Report on the implementation of Directive 2008/52/EC of the European Parliament and of the Council of 21 May 2008 on certain aspects of mediation in civil and commercial matters (the 'Mediation Directive') (2016/2066(INI)) [https:// www.europarl.europa.eu/doceo/document/A-8-2017-0238_EN.html], accessed on $10 / 12 / 2021$.

21. Rewald, R.: Mediation in Europe: The Most Misunderstood Method of Alternative Dispute Resolution, The Wail World Arbitration Report, 2014 [https://www. weil.com/ /media/files/pdfs/WWAR_Newsletter_Spring2014.pdf], accessed on 10/12/2021.

22. Rubinson, R.: Client Counseling, Mediation, and Alternative Narratives of Dispute Resolution, Clinical Law Review 10(Spring) 2004.

23. Shamir, Y.: Alternative Dispute Resolution Approaches and Their Application, 2016 [https://biblioteca.cejamericas.org/bitstream/handle/2015/721/AlternativeDispute-Resolution-Approaches.pdf?sequence $=1 \&$ isAllowed $=\mathrm{y}]$, accessed on 10/12/2021.

24. The Mediation Act 2017 [http://www.irishstatutebook.ie/eli/2017/act/27/enacted/ en/html], accessed on 10/12/2021.

25. Zakon o mirenju (NN 18/11, 2011) [https://www.zakon.hr/z/169/Zakon-o-mirenju], accessed on 10/12/2021. 